\title{
Hybridity and Popular Myth on Kitschy TV Ads in Indonesia, A Case Study of Koyo Cabe Ads in Atlas Aladin and Aladin Mummy Versions
}

\author{
Wildan Hanif ${ }^{1, *}$, Yasraf Amir Piliang ${ }^{2}$ \\ Faculty of Art and Design, Bandung Institute of Technology, Indonesia
}

*Corresponding Author: Wildan Hanif, Faculty of Art and Design, Bandung Institute of Technology, Indonesia

\begin{abstract}
Kitsch element in Koyo Cabe(Pepper Salve) commercial TV ads in Indonesia has a distinctive characteristic, in that it takes both high art (Atlas statue) and a popular myth (Pharaoh mummy) that were processed by the advertiser in such a way so as to attract consumers as soon as possible. The playing of visual and audio marks that the advertiser used was closely related with its product marketing strategy. The research method used in analyzing the kitschy TV ads was qualitative-interpretative by applying Charles Sanders Peirce's pragmatic semiotic approach. The result obtained was that the producer of the ads held a distinctive viewpoint and myth on how the products should be advertised. In the Koyo Cabe ad, both object and person featured in the ad were made symbolically and they indirectly represented the profile of the ad's target, and even they looked like an expression of the advertiser's personal taste and belief on a certain myth.
\end{abstract}

Keywords: Kitsch, TV Ads, High Art Myth, Popular Mitch

\section{Introduction: Kitsch, BAD taste OR MARK Playing?}

Term kitsch is often connected to German word verkitschen, grossly meaning: 'making cheap', and kitschen, literally meaning 'collecting trashes from roads.' Thus, term kitsch is often construed as artistic trash, or bad taste [1] (Piliang, 2012).

The manifestation of a kitsch work is the poor esthetic measure or criterion of the work. However, GilloDorfles, in The Anthology of Bad Taste[2] (1969), refuses to dismiss kitsch as a bad taste or bad art. Kitsch has its own system beyond an art system, though both systems are inseparable. Carol Drew Bentley, in his dissertation A Phenomenological Account of Kitsch-art [3](1988), even asserts that we should be cautious in connecting term kitsch to bad taste. Kitsch is just a form of 'playing' of visual or verbal marks that kitschman (kitsch performer) intends just for pleasure.

Bentley and Anne also explain on the existing paradoxes about the position of kitsch in esthetic domain. Kitsch is a kind of escapism art, that is, when middle class tends to be hedonic, seeking happiness in their leisure time, as a get-away from their daily routines or living problems.

Kitsch should not be connected to just the complex concepts of postmodernism esthetic phenomenon as often written by researchers. Actually, kitsch phenomenon had occurred even far before the heyday of Greece (Hellenism), and will teadily exist in each periode of human civilization and culture [4] (Bentley \& Anne, 1988).

Carol Drew Bentley and Caxole Anne from The Florida State University [5] (1988) describe furthermore the kitsch phenomenon terminologically. They urge the readers to realize philosophically diverse historical, sociological, psychological, and esthetical opinions concerning term "kitsch". First two parts of Bentley and Anne's research are "Social History of Kitsch: Origin of The Term in Earlier Explorations of The Phenomenon" and "Kitsch and Popular Art: An Aesthetic Confusion"[6] (1998), devoted to present general outlooks on kitsch that may be used as an appropriate reference for understanding its terminology which has no a single meaning indeed. Given the multiple faces of kitsch phenomenon, the closure section of Bentley and Anne work shows another approach for what we see as the real problem of kitsch - that is, our lack of understanding on kitschman (kitsch performer) because he or she is closely related to a so-called kitsch art. 
It is here that an investigation into kitsch in TV ads finds a bottom line connecting with Bentley and Anne's research, that is, in revealing the character of kitsch performers who come to be performers (producers/designers of kitschy ads), ad's targets being termed as kitschizen in the context of Indonesian socio-culture. Bentley and Anne express kitschman phenomenon, by among others investigating a famous painting of Leonardo da Vinci, Monalisa, frequently manipulated, or more appropriately 'played' by kitsch performers for just pleasure.[7] (Bentley and Anne, 1988).

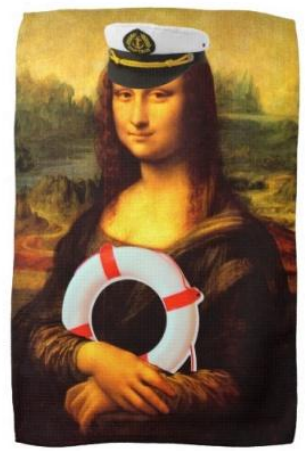

Figure3. A hand towel featuring Naval Captain Monalisa

(Source: http://www.zazzle.com/happy+holidays+kitchen+towels+197732559806164022)

GilloDorfles explains an example of the episode of kitsch in an ad, i.e., by taking Leonardo da Vinci's Monalisa painting placed on a cheese product box, or a Monalisa picture used for a beauty contest poster[8](Dorfles, 1967:19).

One thing commonly used by advertisers is taking a certain myth, either in form of an object or person which is famous or being perceived as a representation of high art (like Monalisa), to be simply attached on a commercial product advertisement. This is one of the kitsch phenomena in ads.

\section{RESEARCH METHODOLOGY}

The research method used in analyzing the present kitsch TV ads was qualitative-interpretative by applying a semiotic-pragmatic approach from Charles Sanders Peirce, an American semiology advocate. Pierce's theory of icon, index, and symbol would make it easier for the researchers to search for both denotative and connotative meanings of the ads investigated. After having revealed both denotative and connotative meanings of the ads, the researchers linked them with the hybridity phenomenon of cultural mark originated in the ad producer's ideology and myth.

According to their objects, Peirce divides marks into icon, index, and symbol [9](Sobur, 2013). Icon is a mark with some resemblance in form with its natural object. It can be meant as a relation between a relatively same mark and its object. Icon suggests a message of matching with originality in form. The simplest sample is one's photo as a representation of himself or herself.

Index is a mark connecting to causality. It is a cause of a message. As a common example, when we are seeing smoke, it is actually a mark of the existence of fire[10] (Sobur, 2013: 42).

Symbol is a mark relating to both its marker and the marked. That anything is symbolized by a mark it is a fact that markers do agree as a general criterion. Take, for example, traffic light. Red light means that any vehicle has to stop. People agree that red light stands for stop [11](Sobur, 2013: 42).

To study kitsch by a semiotic approach, the researchers also referred to Ursula Niklas [12] (1983), 'Kitsch: Semiotic Approach.' Niklas applies a semiotic approach in analyzing kitsch. He points out that there are two ways available to approach kitsch problems on an object: first, we may try to present a depiction of what a kitsch object looks like, or second we focus our attention to human attitude that enables us to perceive a thing as kitsch. Therefore, a process of research on a text that is perceived as kitsch would be faced with two different duties; first, to investigate the natures of esthetical deviation of the object/kitsch work so as to restrict the scope of kitsch in esthetic domain; second is an interpretative analysis of human attitudes on the object, regardless of the criterion of the esthetic value we use, making the object turn into a kitsch. The two approaches can easily be labeled as a kitsch-object approach and kitsch-interpretation approach, respectively.[13] (Niklas: 1983). 


\section{High ART Myth And Popular Myth In Kitschy TV AdS In Indonesia}

In some cases of commercial TV ads in Indonesia, it can be seen that kitsch elements are exploited as optimal as possible by advertisers to promote a consumer product. Elements like and adaptation of popular myth and high art myth and provocation of viewers' feeling by illogic, redundant ways, are used by advertisers to attract the viewers. The impact of kitsch workings in an ad is making the viewers' feeling more sentimental massively. In film jargon, the effect is called overdramatize (excessive dramatization).

For a case of ads that take high art myths and then play them by the advertisers, we selected an example of Pt. Indo AbadiSarimakmur Indonesia's "koyocabe" (pepper salve) product, produced by SPD Production House, and still broadcasted in May 2016 on some private TVs. The high art myth chosen by the advertiser was Atlas myth, i.e., a statue of a Greek God believed as the Earth buffer, who got exhausted from carrying on his shoulder the globe for a very long time, being visited by an Aladin-wearing person, a fairy myth from One Thousand and One Night story. Aladin asked a question to Atlas: "Yaampun, Atlas... pegalya?" (Oh my god, Atlas... you must feel stiff, don't you?") Atlas replied: "Iya, lama-lama pegaljuga"(“yeah, bit by bit I got stiff”). Then, Aladin put aneagle-brand salve on Atlas's shoulder. The salve immediately worked out. In the end of the scene, Atlas recovered and got fit, and even he looked like younger, while playing happily the globe.

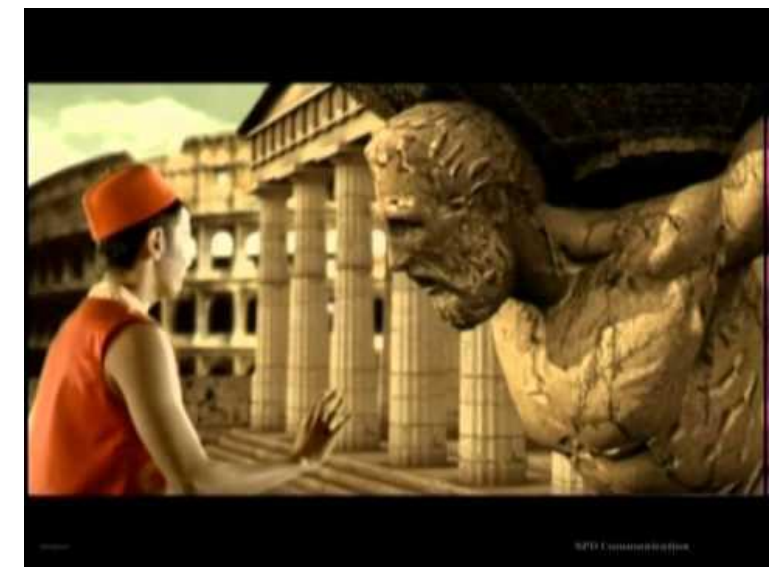

Figure1. Frame from Aladdin and Atlas TV Commercial

If we analyze furthermore the myths chosen on the salve ad, we could see a pattern of combining culturally diverse myths. Atlas myth was obviously taken from Greece, where Greek gods are described as athletic, robust human, a symbol of strength and powerfulness of Greek nation (particularly men). And Aladin myth is a myth of a prince of One Thousand and One fairytale from Middle East area. The two figures were combined into a story aimed to ensure the viewers that the salve product is efficacious. Here the logic emphasized is not a rational-denotative logic, but rather a connotative myth logic by utilizing a tale element. However, both denotative and connotative logics on the ad collaborated to effectively convey a message of the salve efficacy. Let us explore it by using Charles Sanders Peirce's simple semiotic theory to see it more clearly.

Table1. The myth of aladin \& atlas in icon, index, symbol

\begin{tabular}{|c|l|l|l|}
\hline Myth & \multicolumn{1}{|c|}{ Icon } & \multicolumn{1}{c|}{ Index } & \multicolumn{1}{c|}{ Symbol } \\
\hline Atlas & $\begin{array}{l}\text { Statue of a Greek robust man carrying on the } \\
\text { Globe }\end{array}$ & $\begin{array}{l}\text { Atlas as a strong Greek god, } \\
\text { serving to buffer the earth }\end{array}$ & Powerfulness \\
\hline Aladin & $\begin{array}{l}\text { A slim, Arabian-looking man wearing a peci } \\
\text { (Malayan beret), Aladin is flying on a carpet }\end{array}$ & $\begin{array}{l}\text { Aladin as a Prince from a fairy } \\
\text { land who is full of miracles }\end{array}$ & Miracle \\
\hline
\end{tabular}

We see that the advertiser harnessed Atlas's duty of carrying on ceaselessly the earth, as an activity that logically would exhaust his shoulder. Based on the logic, an idea came out to bring in a man named Aladin from Middle East who has a magic or miraculous product, 'koyocabe', to be put on Atlas's shoulder for him to recover and could continue his duty of carrying on the earth. In the context, Atlas was used symbolically to substitute the position of the viewers who were the ad's target (adult men who were exhausted from working), while the position of Aladin substituted the koyo producer (offering koyo product for healing muscular stiff, shooting pain, and exhaust). 
Table2. The Associative meaning of aladin \& atlas

\begin{tabular}{|l|l|}
\hline \multicolumn{1}{|c|}{ Symbolic scene } & \multicolumn{1}{c|}{ Associative meaning } \\
\hline $\begin{array}{l}\text { Atlas got exhausted from carrying on his shoulder the } \\
\text { globe }\end{array}$ & $\begin{array}{l}\text { Adult man who was exhausted from working } \\
\text { physically }\end{array}$ \\
\hline Aladin offered a salve & Koyo producer offered a salve \\
\hline
\end{tabular}

For the case of an adaptation of popular myths, we can compare a popular myth with a different version of the pepper salve product ad, namely Aladin and 'mummy' version. Narration held that Aladin was walking along the lane of Pharaoh's tomb when a "mummy", a cloth-wrapped zombie, suddenly came up, walking wobbly toward him. Aladin at first got shocked and asked "Apaantuh?" (What is it?), but he then smiled and said to the mummy: Why are you walking awkwardly?"

Then, Aladin swiftly ran to the back of the mummy and put a pepper salve. The salve immediately worked, and the mummy who was earlier walking wobbly immediately recovered and even did gymnastic movements together with Aladin.

The quite entertaining ad introduced at least two emotional sentiments to provoke the viewers' attention. First, a nervous and scared feeling, because a horrifying mummy creature came out suddenly and approached Aladin. Second, a comforted and happy feeling, because it turned out that Aladin was not afraid of the mummy at all. He even helped relieve the stiff and shooting pain the mummy was suffering, so he could perform gymnastics together with the mummy.

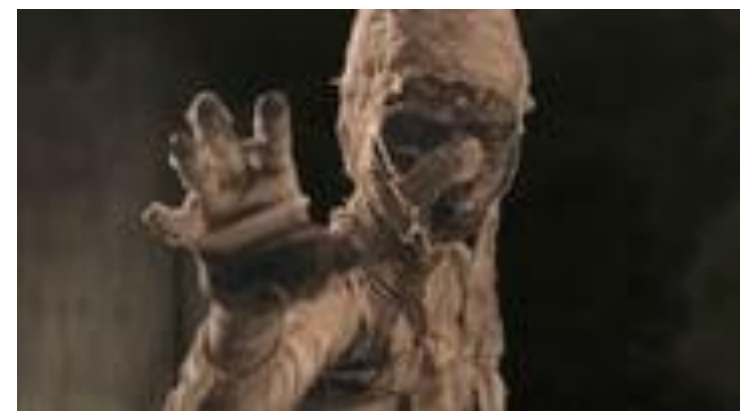

Figure2. The mummy who walks wobbly in Aladdin vs Mummy TV Commercial

In the case of Aladin and Mummy ad, it clearly appears that the sentimental elements to arise from the viewers' feelings were fearful and simultaneously happy. Or, in term of genre, the ad took a comedian horror genre. A horror element by featuring an ala Egypt zombie (mummy) became a quite attracting provocation. The viewers firstly might expect that it was not an ad but rather a part of film scene. It was when Aladin put a pepper slave on the mummy's shoulder that the viewers realized that it was just an ad.

The adaptation process that took place in the ad was of double layers. In the first layer adaptation the ad adapted a story of mummy in popular culture, i.e., a horor film on mummy, while in the second layer adaptation the ad took a mummy myth as a horrifying creature, even for those who have not known any form of mummy appearance.

In the first layer, the viewers iconically saw a wrinkled human body with a partly open face, whose body was cloth-wrapped totally, walking wobbly. Then part of the viewers who have ever known any appearance of mummy from film, novel, or comic immediately expected that it was a mummy, a zombie in ancient Egypt legend. It could be explained as a common semiotic process as follows:

Table3. The myth of aladinvs mummy in icon, index, symbol

\begin{tabular}{|l|l|l|}
\hline \multicolumn{1}{|c|}{ Icon } & \multicolumn{1}{c|}{ Index } & \multicolumn{1}{c|}{ Symbol } \\
\hline A clot-wrapped, wobbly walking zombie & Mummy (corpse in ancient Egypt culture) & Horrifying thing \\
\hline $\begin{array}{l}\text { A slim, Arabian-looking, curl-hair youth } \\
\text { wearing an Aladinpeci(Malayan beret) }\end{array}$ & $\begin{array}{l}\text { Aladin (An Arabic prince in One Thousand } \\
\text { and One tale) }\end{array}$ & $\begin{array}{l}\text { One with a magic/ } \\
\text { miraculous object }\end{array}$ \\
\hline
\end{tabular}

The absurd, illogical story in the TV ad is actually a trick commonly used in fictitious films. Popular cultures, just like Aladin and Mummy films, the advertiser adapted, became a kitsch when they were employed as optimal as possible to sell pepper salve products. A process of borrowing popular cultural myths like Aladin and mummy has been duplicated and reproduced in attempt to promote a 
product. If the Aladin and mummy stories were only part of a film scene indirectly related to selling a certain product, the nature of kitsch would be quite biased or disguised, given that one of the characteristics of kitsch is that it is intended to raise economic value.

Table4. The Associative meaning of aladinvs mummy

\begin{tabular}{|l|l|}
\hline \multicolumn{1}{|c|}{ Symbolic scene } & \multicolumn{1}{c|}{ Associative meaning } \\
\hline The mummy was walking wobbly & The man was exhausted and tired from working physically \\
\hline Aladin put a salve & The salve producer demonstrated the benefit of the salve \\
\hline
\end{tabular}

Kitsch has a very close relation with economic benefit value maximally, because kitsch calls on the whole people of all strata, by provoking the effect of peculiarity and strangeness - as its raison d'etre - to persuade as many masses as possible [14](Piliang, 2012: 189). An effort to make high art massive, intended to attract mass, is a characteristic of kitsch so often practiced in advertisement world.

\section{WHY SHOULD MYTHS FROM OUTSIDE INDONESIA BE HYBRIDIZED?}

The questions that arise from mixing some culturally different myths, which are then stringed up into a story so as to convey the message of the product ad, are: Do Indonesian viewers/the ad's target can comprehend and understand well the ad message? And, secondly, do Indonesian viewers know the stories of Atlas, mummy, and Aladin? Given that they are not derived from Indonesia's local traditions, unlike MalinKundang and Sangkuriang legends considered as originated in Indonesia.

Popular myths originated in popular tales or cultures such as comics, novels, and films are a fruit of globalization. Contiguity of both cultures and identities has taken place since earlier times and throughout the spheres of globe. Globalization leads to cross-cultures. Indonesia's nation as it looks today is a result of cultural crossing since pre-historic times up to information technology era nowadays. In line with increasingly advanced civilization and technology, cultural crossing process is going on more rapidly as well. Information dissemination is made by governmental institutions too. Since the eras of Hinduism-Buddhism, Kingdom, Islam, European imperialism, independence, Old Order, New Order, Reformation Order, to the present days, the presence of governmental institutions in the Archipelago land have been the most effective means to spread information, ideas, and even ideologies the rulers want to spread. The ideology here may be political, economical, or cultural. The dissemination of information, ideas, and ideologies has been supported by diverse media and technologies in line with the civilization of the era.

Relating to media as a means of disseminating information, electronic media is currently one most massively employed, due to its extraordinary characteristics and reproductive capacity. Television and Internet are media that are still deemed as most effective for disseminating information and spreading ideologies.

Concerning the ads broadcasted on Indonesian televisions to promote any product, the targeted public to reach is the majority of Indonesia's people who still make television as their main means of entertainment and information. Therefore, advertisements would automatically design their ads suitable to the viewpoints, insights, and ways of life of their targeted segment. That is a consequence of a product selling strategy. However, if we scrutinize the Aladin-Atlas ad and Aladin-Mummy ad discussed above, it appears that the message that the advertisers want to convey didn't directly represent the targeted viewers. Does the profile of horrifying mummy can be directly associated by the viewers as a representation of themselves as the ad's target? Atlas, the globe buffer, who after having felt the warmness of pepper salve, was probably closer to the profile of adult male viewers. However, the mummy, who turned to be fit after having a pepper salve put on him, may be more appropriate to be associated with elders or grandparents 60 years old or more, or those who are slim and exhausted from working hard physically.

\section{CONCLUSION}

The process of producing kitsch on TV ads is marked by a practice of taking both popular myths and high art, either from Indonesia's local myths or outside cultures. Diverse ways are pursued by advertisers to stimulate or persuade their viewers. Kitschy TV ads, one of which by taking and mixing high art myths or (ancient or modern) popular myths as the aforementioned pepper salve ad, was one of efforts to attract viewers by a sentimental way, i.e., by exploiting senses of being scared and happy 
simultaneously, irrespective of whether or not it was matching the targeted consumers' behaviors, habits, and insights.

Advertisement producers have their own viewpoints and myths on how their products should be advertised. In some examples of ads, the objects or persons featured on the ad are occasionally not related to the ad's targets' profile, but rather simply an expression of personal taste and even belief. The object or figure turns to be a myth in the mind of the product owner. In this case, cooperation between the production house that produces the ad and its client/product owner becomes of high importance. Production house $(\mathrm{PH})$ should accommodate and translate the wishes and ideas of the product owner, meaning capital owner.

\section{REFERENCES}

[1] Piliang, Yasraf Amir,Bayang- bayangTuhan: Agama danImajinasi, Bandung: MizanPublika (2012)

[2] Dorfles, Gillo, The Anthology of Bad Taste,London, Studio Vista-Universe Book(1969)

[3] Bentley, Drew \&Carole, Anne, A Phenomenological Account of Kitsch-art, Florida: The Florida State University (1988)

[4] Bentley, Drew \&Carole, Anne, A Phenomenological Account of Kitsch-art, Florida: The Florida State University (1988)

[5] Bentley, Drew \&Carole, Anne, A Phenomenological Account of Kitsch-art, Florida: The Florida State University (1988)

[6] Bentley, Drew \&Carole, Anne, Social History of Kitsch: Origin of The Term in Earlier Explorations of The Phenomenon, and Kitsch and Popular Art: An Aesthetic Confusion (1998)

[7] Bentley, Drew \&Carole, Anne, Social History of Kitsch: Origin of The Term in Earlier Explorations of The Phenomenon, and Kitsch and Popular Art: An Aesthetic Confusion (1998)

[8] Dorfles, Gillo, The Antology of Bad Taste, Universe Book, p.19, New York(1969)

[9] Sobur, Alex, SemiotikaKomunikasi, Bandung, PT RemajaRosdaKarya(2013)

[10] Sobur, Alex, SemiotikaKomunikasi, Bandung, PT RemajaRosdaKarya(2013)

[11] Sobur, Alex, SemiotikaKomunikasi, Bandung, PT RemajaRosdaKarya(2013)

[12] Niklas, Ursula, Kitsch: A Semiotic Approach, Semiotics 1981, Springer, Boston, MA (1983)

[13] Niklas, Ursula, Kitsch: A Semiotic Approach, Semiotics 1981, Springer, Boston, MA (1983)

[14] Piliang, Yasraf Amir, SemiotikadanHipersemiotika, kode, gaya, danmatinyamakna, Bandung: PenerbitMatahari (2012)

\section{AUTHORS' BIOGRAPHY}

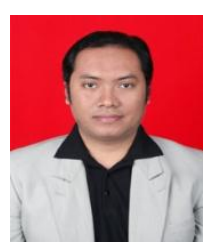

Wildan Hanif, known as Lecturer in Fine Arts in Institut Seni Budaya Indonesia (ISBI) Bandung. He also a Graphic Designer, Calligrapher, and Public Service Filmmaker. Graduate from Visual Communication Design Bandung Institute of Technology (Bachelor and Master). He was pursuing a degree in the Art and Design ITB, for PhD.

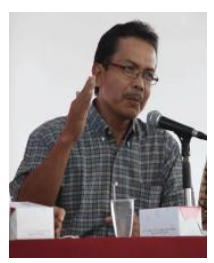

Yasraf Amir Piliang, known as Cultural Expert, Semiotician, and Professor of the Faculty of Art \& Design Bandung Institute of Technology (ITB). His books in great demand as references to contemporary culture with cultural studies approach.

Citation: Wildan Hanif, Yasraf Amir Piliang. "Hybridity and Popular Myth on Kitschy TV Ads in Indonesia, A Case Study of Koyo Cabe Ads in Atlas Aladin and Aladin Mummy Versions". International Journal of Humanities Social Sciences and Education (IJHSSE), vol 5, no. 3, 2018, pp. 85-90 doi: http://dx.doi.org/10.20431/2349-0381.0503008.

Copyright: (C) 2018 Authors. This is an open-access article distributed under the terms of the Creative Commons Attribution License, which permits unrestricted use, distribution, and reproduction in any medium, provided the original author and source are credited. 